\section{Considering Modern Trends in Digital Marketing}

\author{
Milica Slijepčević, Ivana Radojević,
}

Nenad Perić

\begin{abstract}
The authors of this paper have analysed the current and future tendencies in digital marketing communications (DMC). Digital communications are an area of fast and frequent changes that lead to shorter communication between the message sender and receiver, thus speeding up the process and making it more complex. In order to survive in a dynamic environment, companies need to be visible and directly linked to their target groups. Moreover, it is vital that they understand well their digital environment and are prepared to take proactive steps to make their marketing communication successful. Acceptance and application of new trends in the field of digital marketing is a milestone in the business of an organization. The need for a proactive approach to changes is evident, as the organizations that first introduce the user-oriented innovations shall receive consumer attention and funds. $A$ detailed and concise review of the current situation and the forecasts for the future are presented, to allow the expert and scientific public to plan future research in this field. An overview of the challenges and opportunities facing this innovative area provides a valuable insight and helps create a successful marketing communications strategy.
\end{abstract}

Keywords: digital marketing communication, social media, new trends, interactive content, content marketing 
TABLE 1: Global average number of social media accounts

\begin{tabular}{|l|c|c|c|c|c|c|c|}
\hline \multicolumn{7}{|c|}{ Global average number of social media accounts } \\
\hline \multicolumn{1}{|c|}{ Over time } & $\mathbf{2 0 1 3}$ & $\mathbf{2 0 1 4}$ & $\mathbf{2 0 1 5}$ & $\mathbf{2 0 1 6}$ & $\mathbf{2 0 1 7}$ & $\mathbf{2 0 1 8}$ & $\mathbf{2 0 1 9}$ \\
\hline Global Average & 4.3 & 4.8 & 6.3 & 7.6 & 8.0 & 8.6 & 8.5 \\
\hline Gen Z & 4.4 & 4.8 & 6.9 & 8.0 & 9.0 & 9.7 & 9.0 \\
\hline Millennials & 5.1 & 5.7 & 7.4 & 8.9 & 9.3 & 9.7 & 9.1 \\
\hline Gen X & 4.0 & 4.3 & 5.6 & 6.8 & 6.9 & 7.1 & 7.0 \\
\hline Baby Boomers & 2.6 & 2.8 & 3.5 & 4.3 & 5.0 & 5.1 & 5.0 \\
\hline
\end{tabular}

SouRcE: Adapted from GlobalWebIndex's flagship report on the latest trends in social media (Mander \& Kavanagh, 2019).

\section{CURRENT GLOBAL TRENDS IN DIGITAL MARKETING}

A global number of the Internet users continues to increase up to 366 million, making a total of 4.479 billion users in 2019 (October 2019). That is a 10\% increase in the past year. Moreover, global number of unique mobile users has increased by $2.4 \%$, to 5.155 billion unique users (123 million new mobile users) compared to the last year. The total global number of social media users in 2019 amounted to 3.725 billion, growing by $9.6 \%$ in comparison to 2018 . The highest increase of over $15 \%$ occurred in a group of people who use social media on mobile devices. With a total number of 3.66 billion users worldwide (Kemp, 2019). Yuri Musienko (2019) predicts that in 2020, the digital marketing will aim the smartphones and mobile applications, the Internet services and video and social networks.

Investigating time spent on the Internet, quality of content and it impact on people's life resulted in the introduction of new digital wellbeing tools for the Internet users. The Apple's iOS 12 update - Screen Time feature (Newman, 2019), Google`s Digital Wellbeing feature, Facebook's Your Time on Facebook feature and Instagram`s Your Activity feature provide analysis on a user's screen time, the number of his daily pickups or time spent daily on a particular social media (Mander \& Kavanagh, 2019). This, among other things, somewhat affected a drop of some social media accounts in 2019, as can be seen in the Table 1. The global trend of the average number of social media accounts is shown in the table below.

Social media platforms occupy an important position in digital marketing plans, as their potential reach is extremely large. The $45 \%$ of the world's population - 3.5 billion people are now social media users (Kemp, 2019). The Figure 1 below presents the global number of active users of top social platforms, based on monthly active users study. As one of the fastest-growing social media networks, Facebook is still the largest social network worldwide. In the third quarter of 2019, Facebook accounted for 2.45 billion monthly active users (Statista, 2019). Their users have the opportunity to share their own experience and, with the help of other users, brainstorm to develop an opinion on a product/service, company, brand, etc. (Akar \& Topcu, 2011; Kim \& Ko, 2012).

On the other hand, Facebook Messenger had 1.3 billion monthly active users in the same period (Sta-

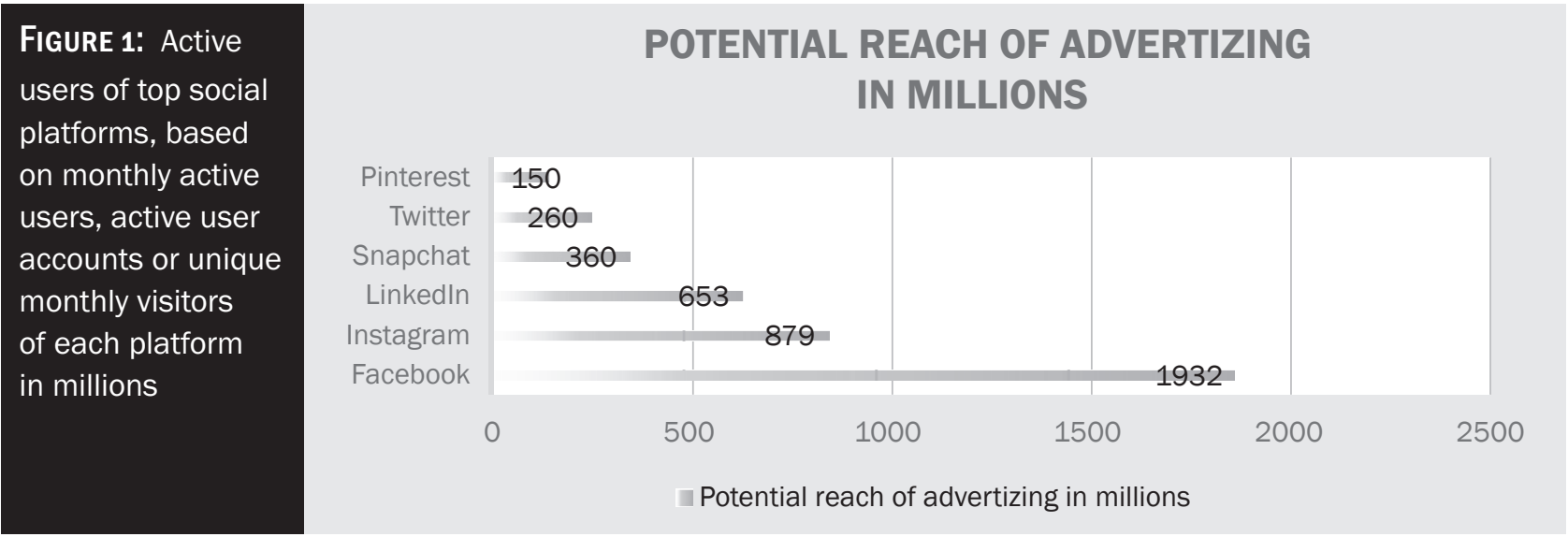

SOURCE: Adapted from Global Digital Report 2019 (Kemp, 2019) 
tista, 2019). In just one year, the daily watch time for Facebook Live videos have quadrupled (Thomson, 2019). Moreover, these videos make six times as many interactions as traditional videos. Additionally incredible, the audience is kept watching three times longer compared to the recorded videos (Thomson, 2019).

Customers are searching for different types of information about organizations, brands, products and services online. According to 2019 State of Conversational Marketing Report, $42 \%$ of customers expect an immediate response within 5 seconds, whereas $36 \%$ expect a response within 5 minutes, from chatbots (Kilens, 2019).

Usually, customers prefer reviews, video instructions, personal experiences of other users and open discussions among social media groups. Digital marketing institute states that $86 \%$ of female users consult social media before choosing a product. Other research reveals that $70 \%$ of active social network users, before making a purchase, seek additional information about the product or service on social media sites (Kim \& Ko, 2012). According to research conducted by Wyzowl (2018), incredible 95\% of respondents said that they have watched a video about products or services they were interested in buying and the number of such respondents increased to 96\% in 2019 (Wyzowl, 2019). Another research revealed that $94 \%$ of customers would remain with the organizations that communicate transparently and clearly (Denis, 2019).

Influencers are today's first face of brands. Working with influencers is a new way of gaining more audience and spreading good electronic word of mouth (eWOM), particularly for small and medium enter- prises (SME). Different authors consider eWOM an influential marketing instrument (Bickart \& Schindler, 2001; Kumar \& Benbasat, 2006; Zhang, Craciun \& Shin, 2010; Erkan \& Evans, 2016). Farmer (2017), defines influencers as persons who can influence attitudes or decisions (Vered, 2007) of other people. Influencers and companies can use different social media platforms to interact, communicate and engage with the target audience and facilitate and increase the outreach and influence (Arora at al., 2019). Most common are Instagram and YouTube, but the influencers also operate on the Twitter, Facebook, LinkedIn, Snapchat and, more recently, on TikTok.

During 2018, the brands engaged nearly 590,000 influencers globally, who shared over 2.6 million ad posts on the Instagram with the total of 2.9 billion engagements generated from these posts (Buzzoole, 2019; Desreumaux, 2019).

The audience trust the digital opinion leader - the influencer they follow. They influence the attitudes, decisions and behaviour of their audience of followers (De Veirman, Cauberghe \& Hudders, 2017). According to the Digital Marketing Institute (2018), 86\% of female users consult social media before choosing a product. Hiring influencers in digital marketing communication can ensure a high return on investment (ROI) (Enke \& Borchers, 2018). Moreover, it facilitates the SME to promote different products or services. Sproutsocial (2017) research revealed that the majority of consumers $(86 \%)$ buy the brands that appear honest and friendly (83\%). They want to see the companies using the social media, inter alia, as a customer care channel. As much as $60 \%$ of users say they

TABLE 2: Video Trends in 2019

\begin{tabular}{|l|c|c|c|}
\hline Channel & $\begin{array}{c}\text { \% of video marketers } \\
\text { that use this type of } \\
\text { video }\end{array}$ & $\begin{array}{c}\text { Increase/decrease of video } \\
\text { marketers that use this type of } \\
\text { video compared to 2018 }\end{array}$ & $\begin{array}{c}\text { \% of video marketers } \\
\text { that say it has been } \\
\text { successful for them }\end{array}$ \\
\hline YouTube & $87 \%$ & Same number & $80 \%$ \\
\hline Facebook video & $84 \%$ & up from 68\% & $85 \%$ \\
\hline Instagram video & $51 \%$ & Up from 41\% & $88 \%$ \\
\hline Linkedln video & $51 \%$ & Up from 38\% & $75 \%$ \\
\hline Twitter video & $45 \%$ & Up from 39\% & $71 \%$ \\
\hline Webinar & $41 \%$ & Down from 44\% & $83 \%$ \\
\hline Facebook Live & $35 \%$ & Up from 34\% & $74 \%$ \\
\hline Interactive video & $23 \%$ & Up from 20\% & $83 \%$ \\
\hline Instagram TV & $17 \%$ & / & $53 \%$ \\
\hline 360 Video & $14 \%$ & Down from 15\% & $74 \%$ \\
\hline Snapchat & $12 \%$ & Up from 11\% & $50 \%$ \\
\hline Virtual reality & $11 \%$ & Down from 14\% & $64 \%$ \\
\hline
\end{tabular}

SouRcE: Adapted from Video Marketing Statistics 2019 (Wyzowl, 2019). 
discover new products on the Instagram (Instagram, 2019 ) and $70 \%$ of the Pinterest users use this network to find new and interesting products (Pinterest, 2019).

According to Sproutsocial (2017), 51\% of customers claim they would unfollow a brand that annoyed them on a social media, whereas $23 \%$ would walk away from such a brand completely, vowing never to buy from it again.

Another study shows that personalized email campaigns receive $29 \%$ higher email open rates and $41 \%$ higher click-through rates than the traditional emails, with no personalization.

Primarily, the organizations need to make a clear and integrated digital marketing strategy. According to researches, almost $50 \%$ of organizations do not have such a strategy in place. In the online marketing, the lack of clear strategy and transparent goals leads to choosing irrelevant key performance indicators (KPIs) for measuring organizational success or investing in the tactics that will lead the organization in the wrong direction.

Using social media networks, organizations can reach their target audience in a simple and fast way. Modern, online customers are seeking for more visual and interactive content, new experience and a higher level of interactivity. Interactive content is more engaging, stands out, grows awareness of a brand and keeps the audience present on the organization's website (Thomson, 2019).

\section{PREDICTIONS OF FUTURE DIGITAL MARKETING TRENDS}

According to Thomson (2019) the top marketing trends for 2020 are the following:

1. Shoppable Posts,

2. Virtual and Augmented Reality (VR \& AR),

3. Interactive Content,

4. Personalization,

5. Content Marketing,

6. Video Content,

7. SERP Position Zero,

8. Google Ads Smart Bidding.

Moreover, Dave (2019) says that soon artificial intelligence (AI) will become the driving force of a large number of industries. For the time being, it has been implemented in various areas, such as basic communication, product recommendations, content creation, email personalization, e-commerce transactions. Some companies use AI in chatbots for providing quick answers, resolving complaints, offering additional content, assisting with registration or requests (Musienko, 2019). By 2020, 90\% of organizations that use online marketing will practice at least one shape or form of marketing personalization (Pemberton, 2018). On the other hand, almost half of the customers will disregard brands that are sending irrelevant advertisements (Briggs, 2016; Youn \& Kim, 2019).

Scaling the personalization represents the biggest challenge in the personalization process. The tools for personalization that every organization needs include the analytics platforms (Google Analytics, Heap Analytics and Crazy Egg) and data management platforms (Customer relationship management software, Post-click landing page platform, Email marketing platform, Tag management platform, Demand-side platform) (Quick, 2019).

Segmenting the content into atoms and dynamic components for targeting and reuse, with a final goal to capitalize on personalized experience, will make organizations able for better uniting customer data with relevant content, and, finally, more competitive on the market (Pemberton, 2018).

Facebook Messenger bot, used by MasterCard, applies natural language processing (Siu, 2019) software to communicate with customers like a human. In addition, AI is implemented in programmatic advertising. Programmatic demand-side platforms apply hundreds of targeting signals to automate ad buying, so that a company can target more specific audience. Using AI to match customer's skin tone with a foundation, personalizing shopping experience through the virtual make-up testing in AR represent the regular activities in Sephora's endeavours to focus on their customers and make the shopping experience personalized for them (DeNisco Rayome, 2018). Predictions are that by $2020,85 \%$ of customer relations with a business will be managed without any human interaction (Gigante, 2019; Baumgartner, Hatami \& Valdivieso, 2016).

It is expected that, in the next year, the shoppable post, interactive content, $\mathrm{AR}$ and $\mathrm{VR}$ will be more popular and more frequently used in digital marketing campaigns. Allowing the customers to purchase directly from an organization's post on Facebook, Pinterest or Instagram is a new, fast-spreading trend, that should be placed on the top of digital marketing plans.

Already, top brand companies are using $A R$ to reach the target audience in an innovative and very immersive ways. Companies such as IKEA, Coca-Cola, Zara, PEZ, Lacoste, Converse, Tesco, Cadbury, BIC Kids, New York Times, Petron Tequila, MTV and the 
like are endeavouring to strengthen their brands by engaging the customers using AR (Paine, 2019).

Whether through the customers visualization of how products might look in their homes while shopping online or through offering the opportunity to superimpose viewers with their favourite music star, taking customers on a virtual tour of the place where their favourite brand is made, a possibility to see how different models of shoes might look on their feet (Paine, 2019) the augmented reality leads the marketing at the next level. Making more interactive experience, increasing involvement and strengthening connections with their customers, those companies are pioneers of augmented reality marketing.

Furthermore, connecting with the target audience through sending personalized email, offering personalized experience, can lead to a higher engagement and more conversions (Thomson, 2019). Engaging and a high-quality content enables the organizations to communicate as experts with their target audience. More than that, it makes messages more visible in search engines. The axiom of digital marketing, content is a king, must be followed.

Another important digital marketing tool for the next period will be video, especially the live video, that keeps the audience engaged three times longer than a recorded video. New Google Ads updates, announced by Google, will lead to automation and smart bidding. Companies are striving to have a stronger presence on the Internet in general (Hennig-Thurau et al., 2010; Rangaswamy, Giles \& Seres, 2009), mainly on the most popular of all - search engines (SE) (Dwivedi, Kapoor \& Chen, 2015). The businesses can communicate with their target audience at any time and from anywhere, $24 / 7$ two-way interactively, using viral marketing. Different authors find this a robust and universal alternative channel for delivering information (Chu, 2011; Schulze, Scholer \& Skiera, 2014).

Being No. 1 is no longer the main goal, because the position zero - the top spot in SERP - will be the first result that the users view (Thomson, 2019). Position zero is a featured snippet of text appearing at the top of the search result pages (Denis, 2019). It provides brief information on the key points related with the search on a link. To optimize bids, Google Ads starts using machine learning. This change has introduced new opportunities for maximizing conversion rates.

Several authors made some interesting predictions. Srivastav (2017) predicted that the global growth of the digital software industry will reach $\$ 74.96$ billion until 2020. Furthermore, Mitchell (2018) predicts the increase in digital marketing budget that will account for incredible $87 \%$ of all marketing budgets by 2022 .
Using voice as a brand and marketing advantage is new and up to date and moving from voice search to voice engagement is expected soon (Abramovich, 2018).

\section{CURRENT AND FUTURE CHALLENGES OF USING DIGITAL TECHNOLOGIES IN DIGITAL MARKETING COMMUNICATION}

One of the biggest challenges of new digital communications is the lack of fundamentals and basic elements of personal connection such as empathy, personal touch, eye contact and the like.

Digital and social media addiction is a disease of the new age. Designing for the addiction and ethical aspect of this topic are considered both by engineers and public (Newman, 2019). Changing algorithms is a must. Issues that must be considered in further researches refer to the harmful impact of digital media - how ethical it is to use notifications that are dripping with dopamine or showing the content that misleads the consumer. Also, the need to better know the importance of 'digital well-being' will push a new wave of articles about this topic. A large number of people feel pressure to delete their social media accounts to preserve their real-life and mental health. The development of new software and dashboards for maintaining social media and digital addiction requires full attention of the academic community.

The moment when influencer marketing become mainstream made a big change at that scene. The collective micro-networks become powerful with an individual's reach and scale (Schouten, Janssen \& Verspaget, 2019). Companies need to change the old habit of working with just a single influencer and switch to a network of relatable peers (Greenwood, 2019).

Digital channels, where companies cannot accurately track shared content (private messaging apps, SMS or emails) are called "dark social" (Valentine, 2019). Sending copied URL via an instant messaging or email or switching from a secure (https) to a non-secure (HTTP) site, the generated traffic is presented as direct in the majority analytics programs (Van Loon, 2019). According to research, the share of dark social as a percent of on-site shares accounts for $84 \%$, globally (RadiumOne, 2016). Consumers usually share content and information (in 63\%) using dark social channels ( $20 \%$ share only via these channels), compared to $54 \%$ that use open social media platforms (Glenday, 2019). The global, as well as local companies, must target and optimize online content to run simultaneously ATL awareness campaigns and easy- 
to-share digital content that can be used and shared at any time privately (Errmann, Seo, Choi \& Yoon 2019). Furthermore, direct interaction with customers, more relevant and sharable content will be highly appreciated by customers (Valentine, 2019; Mayrhofer, Matthes, Einwiller, \& Naderer, 2019).

Even though the YouTube is recommended after the age of 13, the children younger than that age are using it and have their own YouTube channels (TurViñes; Núñez-Gómez \& González-Río, 2018). This topic requires an additional research. Advertising recognition is crucial for all audience, especially for children. It is crucial because of further activation of children's associative networks, which subsequently help them critically evaluate the advertisement and prevents them from being subconsciously persuaded by advertising (De Jans et al., 2018).

As $83 \%$ of companies state, that video content has increased their conversion, furthermore $96 \%$ of customers are sure that the video helps them to understand the product/service and finally, 65\% of viewers visit the site, and 39\% contact the company after viewing the video (Wyzowl, 2019). Companies must provide highly-personalized experience for their customers across the board because they expect the brands they engage with to enable them that.

Around the world, young adults are among the most active social media users, spending 170 min per day in North America, 232 min per day in Latin America, 180 min per day in Europe and 165 min per day in Asia (Mander, 2019). According to the Pew Research Center, $80 \%$ of the US adults aged $18-29$ use Facebook, $71 \%$ use Instagram, $78 \%$ are on the Snapchat and $45 \%$ say they use Twitter. Usage rates for all these platforms, except for Facebook, are higher among the younger than the older adults, who have not abandoned Facebook (Smith and Anderson, 2018). The American Internet users aged 16 - 24 spend 165 min a day on social media networks/services, while those between 35 and 44 spend only 105 min a day using social media (GlobalWebIndex and Statista, 2016). College students in the United States are particularly active social networkers. In particular, $47 \%$ of college women and $34 \%$ of college men spend more than six hours per week using social media (HERI, 2016).

For an organization to be competitive, it has to focus on various digital communication channels for integration and stimulation of customer loyalty. Therefore, the research of needs, preferences, habits, wishes and demands of the current and potential customers and ways of keeping them engaged, must be the primary activity of all companies.
Retaining customers helps increase the revenue, because when you maintain your existing customers, they tend to tell their friends and give you referrals. Also, loyal customers are likely to be more direct and honest about any issues or problems, giving you a chance to improve your brand.

\section{CONCLUSION}

Digital marketing as a process of fulfilling marketing and business aims by using digital technologies, must be prioritized in the marketing plans. In order to improve customer experience by responding to their needs, organizations around the world have realized how important it is to keep up with and apply new digital marketing trends. Merging digital and traditional methods for more accurate fulfilment of customers' needs makes organizations more competitive and stronger on the market. New market opportunities are created with the introduction of new digital technologies and companies, in order to stay competitive and survive on the market, must adopt and implement them in their daily routine.

Digital marketing's reach and boundaries are so dynamic that strategic content delivery requires a rising number of platforms and channels. Virtual and augmented reality remain an area that many companies still have to research.

Digital marketing communications represent the most important modern concept that may be considered a fast-changing part of new technologies. In the process of attracting high-quality customers, the adoption and evolution of fast digital marketing changes will make a difference between a successful and unsuccessful organization. Target audience and customers are online, using different forms of social media. This represents a great opportunity for companies and for the fulfilment of their KPIs, given they can collect and analyse customers online behaviour.

In today's digital market world, consumers want to be guided in making informed purchasing decisions and not marketed upon. That's why personalization, content marketing and interactive content are important for attracting consumer interest, lead the consumers on the purchaser's path and enhance business outcome.

Engaging and interactive content is expected to become increasingly important for gaining consumer interest and enhancing customer experience. While digital marketing evolves with the consumer's expectations and desires, these developments are the start of new industry changes. 
1. Abramovich, G. (2019) The 5 Biggest Marketing Trends For 2019. Retrieved from https://cmo.adobe. com/articles/2018/12/the-5-biggest-marketingtrends-for-2019.html\#gs.vi33g6

2. Akar, E., \& Topcu, B. (2011). An examination of the factors influencing consumer's attitudes toward social media marketing. Journal of Internet Commerce, 1(10), 35-67. https://doi.org/10.1080/15332861.2011.5 58456

3. Arora, A., Bansal, S., Kandpal, C., Aswani, R., \& Dwivedi, Y. (2019). Measuring social media influencer index- insights from Facebook, Twitter and Instagram. Journal of Retailing and Consumer Services, 49, 86-101. https://doi.org/10.1016/j. jretconser.2019.03.012

4. Baer, J. (2019). Social Media Usage Statistics for 2019 Reveal Surprising Shifts. Retrieved from https://www. convinceandconvert.com/social-media-research/ social-media-usage-statistics/

5. Baumgartner, T., Hatami, H., \& Valdivieso, M. (2016). Why salespeople need to develop machine intelligence? Retrieved from https://hbr.org/2016/06/ why-salespeople-need-to-develop-machineintelligence

6. Bickart, B., \& Schindler, R. M. (2001). Internet forums as influential sources of consumer information. Journal of Interactive Marketing, 15(3), 31-40. http:// doi.org/10.1002/dir.1014

7. Briggs, F. (2016). Almost Half Of Consumers Will Reject Brands Sending Irrelevant Or Too Many Ads, Study Shows. Retrieved from https://www.forbes. com/sites/fionabriggs/2016/04/18/almost-half-ofconsumers-will-reject-brands-sending-irrelevant-ortoo-many-ads-study-shows/\#18d6bc45769b

8. Buzzoole. (2019). Global use of \#ad in 2018. Retrieved from https://cdn2.hubspot.net/hubfs/3813671/ content-download/Global-Use-of-\%23ad-in-2018.pdf

9. Chu, S.-C. (2011). Viral advertising in social media: participation in Facebook groups and responses among college-aged users. Journal of Interactive Advertising, 12, 30-43. https://doi.org/10.1080/152520 19.2011.10722189

10. Dave, N. (2019). 42 Digital Marketing Trends You Can't Ignore in 2020. Retrieved from https://www. singlegrain.com/digital-marketing/digital-marketingtrends-2020/

11. Denis, D. (2020). 10 Biggest Content Marketing Trends that Will Dominate 2020. Retrieved from https://www.coredna.com/blogs/content-marketingtrends

12. De Jans, S., Vanwesenbeeck, I., Cauberghe, V., Hudders, L., Rozendaal, E., \& van Reijmersdal, E.
A. (2018). The Development and Testing of a Childinspired Advertising Disclosure to Alert Children to Digital and Embedded Advertising. Journal of Advertising, 47(3), 255-269. https://doi.org/10.1080/00 913367.2018.1463580

13. DeNisco Rayome, A. (2018). How Sephora is leveraging $\mathrm{AR}$ and $\mathrm{AI}$ to transform retail and help customers buy cosmetics. Retrieved from https://www. techrepublic.com/article/how-sephora-is-leveraging-arand-ai-to-transform-retail-and-help-customers-buycosmetics/

14. Desreumaux, G. (2019). The Use Of \#Ad Grew By $42 \%$ On Instagram In 2018. Retrieved from https:// wersm.com/the-use-of-ad-grew-by-42-on-instagramin-2018/

15. De Veirman, M., Cauberghe, V., \& Hudders, L. (2017). Marketing through Instagram influencers: the impact of number of followers and product divergence on brand attitude. International Journal of Advertising, 36(5), 798-828. https://doi.org/10.1080/02650487.2017 .1348035

16. Digital Marketing Institute. (2019). 20 influencer marketing statistics that will surprise you. Retrieved from https://digitalmarketinginstitute.com/blog/20influencer-marketing-statistics-that-will-surprise-you

17. Dwivedi, Y. K., Kapoor, K. K., \& Chen, H. (2015). Social media marketing and advertising. The Marketing Review, 15(30), 289-309. https://doi.org/10. 1362/146934715X14441363377999

18. Enke, N., \& Borchers, N. S. (2018). Von den Zielen zur Umsetzung: Planung, Organisation und Evaluation von Influencer-Kommunikation. Wiesbaden, Springer Gabler. https://doi.org/10.1007/978-3-658-211882_12

19. Erkan, I., \& Evans, C. (2016). The influence of eWOM in social media on consumers' purchase intentions: An extended approach to information adoption. Computers in Human Behavior, 61, 47-55. https://doi. org/10.1016/j.chb.2016.03.003

20. Errmann, A., Seo, Y., Choi, Y. K., \& Yoon, S. (2019). Divergent Effects of Friend Recommendations on Disclosed Social Media Advertising in the United States and Korea. Journal of Advertising, 48(5), 495511. https://doi.org/10.1080/00913367.2019.1663320

21. Farmer, N. (2017). The Invisible Organization: How Informal Networks Can Lead Organizational Change. New York: Routledge. https://doi. org/10.4324/9781315238883

22. Gigante, M. (2019). 30+ Artificial Intelligence Statistics for 2019. Retrieved from https://learn. g2.com/artificial-intelligence-statistics 
23. Glenday, J. (2019). 63\% of people prefer to share content on ,dark social' channels. Retrieved from https://www.thedrum.com/news/2019/03/25/63-peopleprefer-share-content-dark-social-channels

24. Greenwood, P. (2019). Why influencers are losing their influence? Retrieved from https://wearesocial. com/blog/2019/05/why-influencers-are-losing-theirinfluence

25. Hennig-Thurau, T., Malthouse, E. C., Friege, K., Gensler, S., Lobschat, L., Rangaswamy, A., \& Skiera, B. (2010). The Impact of New Media on Customer Relationships. Journal of Service Research, 13(3), 311-330. https://doi.org/10.1177/1094670510375460

26. Instagram. Stand out with Instagram. Retrieved from https://business.instagram.com/getting-started/\#whyinstagram

27. Kemp S. (2019). Global digital report 2019. Retrieved from https://wearesocial.com/global-digitalreport-2019

28. Kilens, M. (2019). State of conversational marketing. Retrieved from https://www.drift.com/blog/state-ofconversational-marketing/

29. Kim, A. J., Ko, E. (2012). Do social media marketing activities enhance customer equity? An empirical study of luxury fashion brand. Journal of Business Research, 65(10), 1480-1486. https://doi.org/10.1016/j. jbusres.2011.10.014

30. Kumar, N., \& Benbasat, I. (2006). The influence of recommendations and consumer reviews on evaluations of websites. Information Systems Research, 17(4), 425-439. http://doi.org/10.1287/isre.1060.0107

31. Mander, J., \& Kavanagh, D. (2019). GlobalWebIndex's flagship report on the latest trends in social media. Retrieved from https://www.globalwebindex.com/ reports/social

32. Mayrhofer, M., Matthes, J., Einwiller, S., \& Naderer, B. (2019). User generated content presenting brands on social media increases young adults' purchase intention. International Journal of Advertising. https:// doi.org/10.1080/02650487.2019.1596447

33. Mitchell, V. (2018). Digital advertising continues to dominate marketing budgets. CMO. Retrieved from https://www.cmo.com.au/article/641955/digitaladvertising-continues-dominate-marketing-budgets/

34. Mukherjee, K K., \& Banerjee, N. (2019). Social networking sites and customers' attitude towards advertisements. Journal of Research in Interactive Marketing, 13(4), 477-491. https://doi.org/10.1108/ JRIM-06-2018-0081

35. Musienko, Y. (2019). The main trends of digital marketing in 2020. Retrieved from https://merehead. $\mathrm{com} / \mathrm{blog} /$ the-main-trends-of-digital-marketingin-2020/

36. Newman, N. (2019). Journalism, Media, and Technology Trends and Predictions 2019. Retrieved from https://reutersinstitute.politics.ox.ac.uk/sites/
default/files/2019-01/Newman_Predictions_2019_ FINAL_2.pdf

37. Paine, J. (2019). 10 brands already leveraging power of augmented reality. Retrieved from https://www.inc. com/james-paine/10-brands-already-leveraging-powerof-augmented-reality.html

38. Pemberton, C. (2018). Gartner Top 5 Marketing Predictions for 2018. Retrieved from https://www. gartner.com/en/marketing/insights/articles/gartner-top5-marketing-predictions-for-2018

39. Pinterest. Here's how people shop on Pinterest. Retrieved from https://business.pinterest.com/en/blog/ heres-how-people-shop-on-pinterest

40. RadiumOne. (2016). The dark side of mobile sharing. Retrieved from https://radiumone.com/wp-content/ uploads/2016/08/radiumone-the-dark-side-of-mobilesharing-June-7-2016.pdf

41. Rangaswamya, A., Gilesa, L., \& Seres, S. (2009). A Strategic Perspective on Search Engines: Thought Candies for Practitioners and Researchers. Journal of Interactive Marketing, 23(1), 49-60. https://doi. org/10.1016/j.intmar.2008.10.006

42. Schulze, C., Scholer, L., \& Skiera, B. (2014). Not all fun and games: viral marketing for utilitarian products. Journal of Marketing, 78(1), 1-19. https:// doi.org/10.1509/jm.11.0528

43. Schouten, A. P., Janssen, L., \& Verspaget, M. (2019). Celebrity vs. Influencer endorsements in advertising: the role of identification, credibility, and ProductEndorser fit. International Journal of Advertising. https://doi.org/10.1080/02650487.2019.1634898

44. Siu, E. The Effects of Natural Language Processing (NLP) on Digital Marketing. Retrieved from https:// www.singlegrain.com/artificial-intelligence/effects-ofnatural-language-processing-nlp-on-digital-marketing/

45. Slijepcevic, M., \& Radojevic, I. (2018). Current Trends in Digital Marketing Communication. In: Proceedings of XVI International Symposium: Doing business in the digital age: challenges, approaches and solutions Symorg 2018, (pp. 618-623), Zlatibor: Serbia.

46. Sproutsocial. (2017). The Sprout Social Index: Edition XI: Social Personality. Retrieved from https:// sproutsocial.com/insights/data/q2-2017/\#brandpersonality-the-more-authentic-the-more-effective

47. Srivastav, T. (2017). Global digital marketing software industry set to reach $\$ 74.96$ bn by 2022 . Retrieved from https://www.thedrum.com/news/2017/11/30/ global-digital-marketing-software-industry-set-reach$7496 b n-2022$

48. Statista. (2020). Number of monthly active Facebook users worldwide. Retrieved from https://www.statista. com/statistics/264810/number-of-monthly-activefacebook-users-worldwidel

49. Thomson, C. (2019). Top Marketing Trends For 2020, Forbes. Retrieved from https://www.forbes.com/sites/ 
forbesagencycouncil/2019/10/03/top-marketing-trendsfor-2020/\#6889ba113d5d

50. Tur-Viñes, V., Núñez-Gómez, P., \& González-Río, M. J. (2018). Kid influencers on YouTube. A space for responsibility. Revista Latina de Comunicación Social, 73, 1211-1230. https://doi.org/10.4185/RLCS-20181303en

51. Quick, T. (2019). What is Personalized Marketing \& How Can You Excel at It? [Examples]. Retrieved from https://instapage.com/blog/personalized-marketing

52. Valentine, O. (2019). How brands can capitalise on the rise of dark social? Retrieved from https://wearesocial. com/blog/2019/03/how-brands-can-capitalise-on-therise-of-dark-social

53. Van Loon, A. (2019). How brands can get dark social right? Retrieved from https://wearesocial.com/ blog/2019/02/how-brands-can-get-dark-social-right

54. Vered, Arnon (2007). Tell A Friend: Word of Mouth Marketing: How Small Businesses Can Achieve Big Results. Arnon Vered.
55. Wyzowl. (2019). Video Marketing Statistics 2018 - The State of Video Marketing 2018. Retrieved from https:// www.wyzowl.com/video-marketing-statistics-2018/

56. Wyzowl. (2020). Video Marketing Statistics 2019 - The State of Video Marketing 2019. Retrieved from https:// www.wyzowl.com/video-marketing-statistics-2019/

57. Youn, S., \& Kim, S. (2019). Newsfeed native advertising on Facebook: young millennials' knowledge, pet peeves, reactance and ad avoidance. International Journal of Advertising, 38(5), 651-683. https://doi.org/10.1080/02650487.2019.1575109

58. Zhang, J. Q., Craciun, G., \& Shin, D. (2010). When does electronic word-of-mouth matter? A study of consumer product reviews. Journal of Business Research, 63(12), 1336-1341. http://doi.org/10.1016/j. jbusres.2009.12.011

59. Zhang, C.-B., \& Li, Y.-N. (2019). How social media usage influences $\mathrm{B} 2 \mathrm{~B}$ customer loyalty: roles of trust and purchase risk. Journal of Business \& Industrial Marketing, 34(7), 1420-1433. https://doi.org/10.1108/ JBIM-07-2018-0211

\section{Apstrakt:}

\section{Menjanje oblika digitalne marketinške komunikacije}

Milica Slijepčević, Ivana Radojević, Nenad Perić

Autori ovog rada su analizirali trenutne i buduće tendencije digitalnih marketinških komunikacija (DMK). Digitalne komunikacije predstavljaju oblast u okviru koje se dešavaju brze i česte promene koje vode ka skraćivanju komunikacije između pošiljaoca i primaoca poruke, čime se proces komunikacije ubrzava i čini kompleksnijim. Kako bi opstale u dinamičnom okruženju, kompanije moraju biti vidljive i direktno povezane sa svojim ciljnim grupama. Štaviše, od vitalnog je značaja da dobro razumeju svoje digitalno okruženje i da su spremne da preduzmu proaktivne korake kako bi svoju marketinšku komunikaciju učinili uspešnom. Prihvatanje i primena novih trendova $\mathrm{u}$ oblasti digitalnog marketinga predstavlja prekretnicu u poslovanju organizacije. Evidentna je neophodnost proak- tivnog pristupa promenama, jer će organizacije koje prve uvedu inovacije orijentisane na korisnike dobiti pažnju i prihode potrošača. Predstavljen je detaljan i koncizan pregled trenutne situacije i predviđanja budućih trendova, kako bi stručna i naučna javnost mogle da planiraju dalja istraživanja iz ove oblasti. Pregled izazova i mogućnosti sa kojima se susreće ovo inovativno područje pruža dragoceni uvid i pomaže u kreiranju uspešne strategije marketinške komunikacije.

Ključne reči: digitalne marketinške komunikacije, društveni mediji, novi trendovi, interaktivni sadržaj, marketing sadržajem

\section{Kontakt:}

Milica Slijepčević, milica.slijepcevic@metropolitan. Ivana Radojević, gujanicaivana@yahoo.com Nenad Perić, nenad.peric@metropolitan.ac.rs Univerzitet Metropolitan Beograd, Fakultet za menadžment 